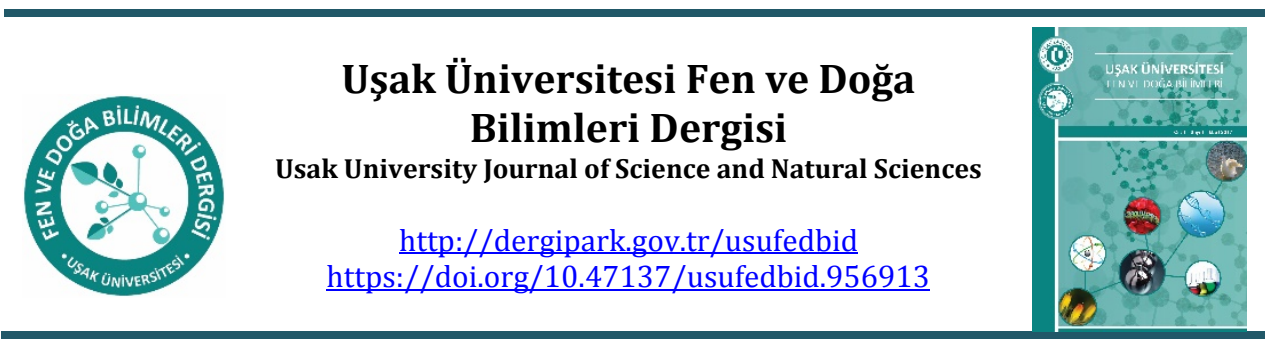

Araştırma Makalesi

\title{
Determination of Genotypic Profiles of Escherichia coli Strains by PFGE Molecular Method
}

\author{
Muhammed İbrahim YAVAN*, Alper KARAGÖZ \\ *Moleküler Biyoloji ve Genetik Bölümü, Fen Edebiyat Fakültesi, Ușak Üniversitesi, Uşak, Türkiye

\begin{abstract}
From the family Enterobacteriaceae is Escherichia coli (E. coli) is a pathogenic bacterium that is getting more important, especially in hospitals, common social areas. Owing to the broad-spectrum beta-lactams (ESBL) they produce, they are usually multi-resistant and are common in intestinal and urinary tract infections. It is of great importance to reduce cross-contamination from public areas and to examine and reveal the genotype structure of the bacteria in question, i.e., to reach fingerprints, subtype sequences of strains. 50 E. coli strains selected in the study were typified by Pulse field gel electrophoresis.
\end{abstract}

Keywords: Escherichia coli, genotyping, PFGE, subtyping.

\section{Özet}

Enterobacteriaceae familyasından Escherichia coli (E. coli), özellikle hastanelerde, ortak sosyal alanlarda giderek daha önemli hale gelen patojenik bir bakteridir. Ürettikleri geniş spektrumlu beta-laktamlar (ESBL) sayesinde genellikle çok dirençlidirler ve bağırsak ve idrar yolu enfeksiyonlarında yaygındırlar. Kamusal alanlardan çapraz bulaşmanın azaltılması ve söz konusu bakterilerin genotip yapısının incelenmesi ve ortaya çıkarılması, yani parmak izlerine, suşların alt tip dizilerine ulaşmak büyük önem taşımaktadır. Çalışmada seçilen 50 E. coli suşu, Pulse field jel elektroforezi ile tiplendirildi.

Anahtar Kelimeler: Alt tiplendirme, Escherichia coli, genotiplendirme, PFGE.

(C)2021 Usak University all rights reserved.

\footnotetext{
${ }^{*}$ Corresponding author:

E-mail: 1843055007@ogr.usak.edu.tr (ORCID ID: 0000-0002-8089-2373)

(C)2021 Usak University all rights reserved.
} 


\section{Introduction}

Escherichia coli, which is part of the Enterobacteriaceae family and was first known by the name bacterium colicommune, was named Escherichia coli by Chalmer and Castellani in 1919 [1].

Warm-blooded animals and humans E. coli of the normal intestinal flora of bacteria that form in the group, as biological classification; Kingdom Eubacteria, Phylum branch, gamma, phylum, class, team and Enterobacteriales Enterobacteriaceae family is located $[2,3]$. Although rarely occurring outside the capsule, many isolates contain a microcapsule containing the $\mathrm{M}$ antigen or a slime layer similarly containing the $\mathrm{K}$ antigen in the polysaccharide structure $[4,5]$.

As a highly complex antigenic structure, E. coli was classified by Kauffman in 1944 within the framework of its antigenic properties. In line with this classification, it is divided into serological groups in the context of 0 -specific polysaccharide chain in lipopolysaccharides in the cell wall, and serologic types in the context of $\mathrm{K}$ and $\mathrm{H}$ antigens [6-11].

Pulsed-field gel electrophoresis (PFGE) is considered the "gold method" of molecular typing methods. PFGE is a genotyping method that has proven to be superior to many other biochemical and molecular typing methods with its high discriminatory power for different bacterial strains [12-21].

In our study, 50 E. coli strains were genotypically typed by Pulse Field Gel Electrophoresis technique.

\section{Materials and Methods}

One colony parallel seeding was performed on Nutrient agar and EMB agar from the bacteria identified at species level by biochemical and molecular methods before each study. The purity of the culture was checked after an overnight incubation. The single colonies here were left to incubate overnight by passage, so that they are suitable for single colony cultivation on Nutrient agar. Colonies grown in pure culture were collected with plastic loop and suspended in $1 \mathrm{ml}$ of cell suspension buffer (HST) (100 mM Tris$\mathrm{HCl}, 100$ mM EDTA, pH: 8.0).

The cell suspension was centrifuged at $2500 \mathrm{x}$ g for 15 minutes (alternatively at $13000 \mathrm{x}$ $\mathrm{g}$ for 2 minutes) at $4^{\circ} \mathrm{C}$. Once again $1 \mathrm{ml}$ of cold HST was added onto the pellet and vortex was performed for a short time. Bacterial density was adjusted with the help of a spectrophotometer (UV / Vis. Spectrophotometer, Boeco, Germany) to be 1 absorbance at $590 \mathrm{~nm}$ (approximately McFarland 4 turbidity). Bacteria suspension was kept at room temperature to be embedded in agarose.

Low melting agarose (LMA) of $2 \%$ in HST was prepared. An agarose mold for each strain was marked and placed in the ice tray. $200 \mu \mathrm{l}$ of the bacterial suspension prepared in HST was taken and added to the tube kept at $50^{\circ} \mathrm{C}$ and containing $200 \mu \mathrm{l}$ of LMA-SDS. Molds were kept at $+4^{\circ} \mathrm{C}$ for 10 minutes until the agarose solidified in order to prepare high quality DNA, so that while early cell lysis and endonuclease activity decreased, homogeneous solidification of agarose was achieved.

$0.5 \mathrm{ml}$ Cell Lysis Solution-1 (HLS-1) (50 mM Tris-HCl pH: 8.0, 50 mM EDTA, $2.5 \mathrm{mg} / \mathrm{ml}$ lysozyme, $1.5 \mathrm{mg} / \mathrm{ml}$ proteinase $\mathrm{K}$ ) was added to $1.5 \mathrm{ml}$ sterile capped tubes. The 
agarose-containing bacteria were removed from the mold and placed in the lysis solution. The molds in HLS-1 were kept at $37^{\circ} \mathrm{C}$ for 1 hour in a shaking water bath. HLS-1 was poured and replaced by $0.5 \mathrm{ml}$ cell lysis solution-2 (HLS-2) (0.5 M EDTA, 1\% sarcosyl, $400 \mu \mathrm{g} / \mathrm{ml}$ proteinase K) solution was added to the tubes. Stored at $55 \mathrm{C}$ for 2 hours in shaking water bath.

After the lysis step, the tubes were kept in ice for at least 15 minutes to solidify the agarose mold. The HLS-2 solution was carefully removed from the tubes. $4 \mathrm{ml}$ of sterile ultrapure water (Reagent Grade Type 1) heated to $50^{\circ} \mathrm{C}$ was added to the tubes with agarose mold and kept in a $50^{\circ} \mathrm{C}$ shaking water bath for 15 minutes. After the water in the tubes was completely aspirated, the washing process with water mentioned in the third item was repeated twice more. The water in the tubes was completely aspirated. The agarose plates were then washed three times with $4 \mathrm{ml}$ of TE $(10 \mathrm{mM}$ Tris-HCL, 0.1 $\mathrm{mM}$ EDTA, $\mathrm{pH}$ 7.6) buffer, each for 15 minutes at $50^{\circ} \mathrm{C}$. Thus, agarose templates containing purified DNA were made ready for cutting with restriction enzymes (RE).

Agarose containing DNA was cut using a scalpel $1 / 4$ rate pattern based on a slide. One of the pieces was placed in $100 \mu \mathrm{l} 1 \mathrm{x}$ Fast Digest buffer and kept in a shaking water bath at $37^{\circ} \mathrm{C}$ for 10 minutes. (Other parts were kept in TE buffer.) Enzyme buffers from the tubes were removed and $100 \mu \mathrm{l}$ of the mixture prepared in number 2 was added to each tube. It was incubated for 2 hours at $37^{\circ} \mathrm{C}$. At the end of the incubation, the tubes were kept in the refrigerator for 15 minutes and the molds were made ready for electrophoresis. 1\% agarose (pulsed-field certified agarose, Bio-rad Laboratories) was prepared to $100 \mathrm{ml}$ in 0.5x TBE (44.5 mM Trismabase, $44.5 \mathrm{mM}$ Boric acid, $1 \mathrm{mM}$ EDTA, pH: 8.0). $1 \mathrm{~g}$ of pulsedfield certified agarose 'was placed in a $200 \mathrm{ml}$ flask and $100 \mathrm{ml} 0.5 \mathrm{x}$ TBE was added on it, stirring gently to distribute the agar. After the agarose dissolved thoroughly, the flask was kept in a $45-50^{\circ} \mathrm{C}$ water bath. The cassette to be poured agarose was prepared. Each of the agarose molds cut with the Restriction Enzyme was placed at the ends of the teeth of the 15 tooth comb (exactly parallel to the tip line of the comb. The head and trailing teeth of the comb were left empty. 45-50 C agarose was poured into the cassette, after freezing, the comb and cassette frame were removed and the solidified agarose on the table was placed in the PFGE tank containing 1900-2000 ml 0.5x TBE buffer.

Electrophoresis applied in CHEF-DR II system.

\section{Results}

50 E. coli strains were found to be clonally related to all strains as a result of PFGE dendrogram. Two major pulsotypes were found among these strains (A-B).

$$
\begin{aligned}
& 1^{\text {st }} \text { Group (A): } 21 \text { STRAINS } \\
& 2^{\text {nd }} \text { Group (B): } 29 \text { STRAINS }
\end{aligned}
$$

Based on the tennover criteria, the similarity rate was found to be $94 \%$. Clone A was $96 \%$ similar in itself and clone B was 99\% similar in itself. Since these similarities were $85 \%$ and above, the strains were evaluated as the same, clonally related and contamination was detected. The clustering rate was found to be $100 \%$. (Figure 1.) 


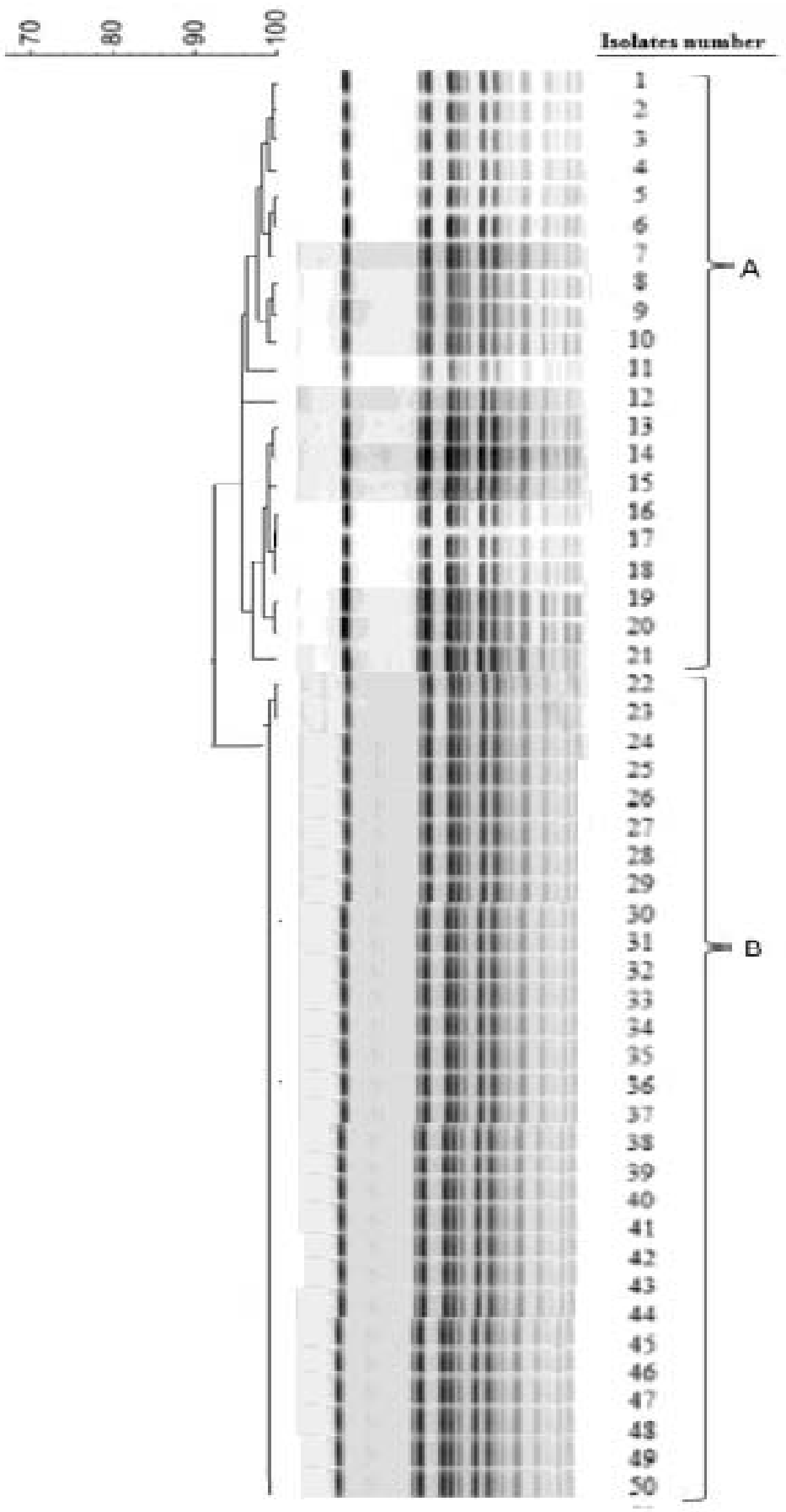

Figure 1. PFGE dendogram image of 50 E. coli strains 


\section{Discussion}

E. coli is a common pathogen and should be investigated for nosocomial infections. To examine clonal relationships of microorganisms; It is getting more important to reveal subtypes of strains in determining whether they have a common origin in terms of hospital outbreaks and food contamination. Methods used in this sense: Amplified fragment length polymorphism (AFLP), flagellin typing (Fla), multilocus enzyme electrophoresis (MEE), nucleotide sequencing, (NS), polymerase chain reaction (PCR), randomly amplified polymorphic DNA (RAPD) and pulsed field gel electrophoresis (PFGE). The most important point to be considered here is the distinctive power of the technique to be used, as well as parameters such as sensitivity, speed, usability, ease of use, cost, reproducibility should be evaluated altogether. In order to say that the methods are effective, they must meet at least a few of the above criteria together [22-25].

The fact that strains that are genetically independent from each other can be easily distinguished, reproducible, and closely related organisms with the same feature can be considered a common feature for all methods. In the selection of the method, the strain should be determined first, then the method to be used in accordance with this strain should be scanned from the literature and finally, the selected method should be optimized for the study. PFGE, refered as the gold standard method, which is a very successful method for subtyping bacteria [26-29].

On the other hand, one of the biggest disadvantages of these methods is; It is the comparison of the studies in different laboratories, although the chemicals used and the environmental conditions are standardized [18].

The main purpose of our study is to type the strains of E. coli bacteria with the PFGE method. The restriction enzyme selection of the bacteria to be used in this method is very important. Considering the restriction enzyme cost, it can be considered as a disadvantage for this method.

50 E. coli strains examined with the PFGE method in the study were found to be clonally related to each other and divided into two major pulsotypes. Tenover criteria were evaluated as an aid to this result. Tenover criteria are very useful in genotyping closely related bacteria, and in the study, it was optimized to the PFGE technique to increase the accuracy of the results and to separate the isolates into their own groups. The PFGE method has proven to be a stronger genotyping method compared to other methods due to its discrimination power.

Comparing the methods for separating DNA molecules; The electrical conduction in the gel has been found to be important, especially the direction of the voltage. This method was chosen due to the fact that the discrimination power is more effective owing to the cross-direction and variable voltage of the PFGE method compared to running the molecules at unidirectional constant voltage as in standard gel electrophoresis.

Its discriminatory power is stronger than conventional electrophoresis; YAC has a great role technically in the separation of human chromosomes that are difficult to analyze by shedding light on the development of the cloning system [18].

Considering that the PFGE method takes time, the PCR melting profile technique can be considered as a different method. This technique is valid in terms of discrimination power, reproducibility and suitability for epidemiological analysis, as well as it has been described as a fast method for giving results. PCR with PFGE is said to be similar in MP 
separation power. Because the technique is time consuming, multiple strain analyzes can complicate the study and also increase economic costs due to complex equipment requirements [17].

Looking at previous studies, 30 E. coli strains were examined and differences were observed in PFGE profiles. In the first profile of the studies, 2 separate strains were identified, and in the second profile 2 similar strains and 5 different strains were identified. In the third profile, 2 closely related; 4 different strains were encountered and 3 strains were analyzed in the last profile.

In our study, $50 \mathrm{E}$. coli strains were examined and all strains were found to be closely related. 2 main pulsotypes were removed. 1. Group A 21 strain; Group B was grouped as 29 strains. Since the profiles supported by the Tenover criteria have $96 \%$ of A clone and $99 \%$ of clone B, it is concluded that the strains are the same. Different strains in other study may indicate possible contamination.

As a result, PFGE is the gold standard method that can be used in the diagnosis of potential outbreaks in common areas of society, such as hospital intensive care units, prison wards, dormitories, etc. In addition, it provides the opportunity to use in a wide range of areas such as disease susceptibility analysis, personalized drug design, gene therapy, genetic tests, forensic medicine, development of high nutritional value products, and breeding studies. Especially in the diagnosis and treatment of infectious diseases, vital developments have taken place in recent years. The most important situation in epidemic research; It is the appropriate categorization of strains that are unrelated or unrelated to the epidemic by subtyping bacteria. Therefore, PFGE is an important tool for distinguishing unrelated strains in outbreak-related analyzes and can determine the direction of outbreak research. In addition, phage typing may be useful in order to identify an isolate that is not related to the epidemic, although the PFGE method with the Xbal enzyme is sensitive. In addition, phage typing can help confirm the associated strains, but may result in fewer tests by reducing the use of more enzymes. Because the phage typing method is faster than the PFGE technique and can be analyzed with less effort than the PFGE method. Within the framework of all this, phage typing from the very beginning of the study can only distinguish the epidemic strain phage type sample and allow further PFGE analysis.

With these methods developed according to traditional analysis methods, unrelated strains are understood more clearly, much more detailed results are obtained in the gel, and these processes can take place in shorter periods of time.

These methods, which also emerged with the development of old methods, brought the world of science to a different dimension with the fragment patterns they created. The PFGE method has been accepted as the gold standard method since it has the power to separate even large DNA fragments and has been accepted in recent years.

Currently, centers have been opened so that these techniques can be better understood, developed, and new ones can be created. This PFGE method is a very good method used to examine the correlation between different individuals of the same species. 


\section{References}

1. Baştürk S. Escherichia coli, Klebsiella pneumoniae, Pseudomonas aeruginosa ve Acinetobacter baumannii Suşlarında Çeșitli Kinolon 49 Grubu Antibiyotiklerin 63 Duyarlılıklarının Araştırılması, Uzmanlık Tezi, Sağlık Bakanlığı Haseki Eğitim ve Araştırma Hastanesi, İstanbul, 2005.

2. Murray PR, Rosenthal KS and Pfaller MA. Medical Microbiology: Enterobacteriaceae. 5th Edition. Philadelphia: Elsevier Mosby; 2005.

3. Tünger A. Asya Mikrobiyoloji: Bakteriyoloji, Viroloji, Mikoloji, Parazitoloji, İmmünoloji. İzmir: Asya Tıp Kitabevi; 2005.

4. Ustaçelebi Ş. Temel ve Klinik Mikrobiyoloji. 1. Baskı. Ankara: Güneş Kitabevi; 1994.

5. Töreci K. Escherichia Türleri, Enfeksiyon Hastalıkları ve Mikrobiyolojisi. Cilt 2, 2. Baskı. Ankara: Nobel Tıp Kitapevleri; 2002.

6. Bilgehan H. Escherichia. In: Bilgehan H (editör). Klinik Mikrobiyoloji Özel Bakteriyoloji ve Bakteri Enfeksiyonları. 10. Baskı. İzmir: Barıș Yayınları Fakülteler Kitabevi; 2000.

7. Baron EJ, Peterson LR and Finegold SM. Enterobacteriaceae. In: Baron EJ, Peterson LR, Finegold SM (eds) Bailey and Scotts. Diagnostic Microbiology. 9th ed. London, St. Louis: Mosby; 1994.

8. Bilgehan H. Klinik Mikrobiyolojik Tanı. 3. Baskı. Ankara: Barıs Yayınları; 2002.

9. Brooks GF, Butel JS, Morse SA, eds. Jawetz, Melnck and Adelberg"s. Medical Microbiology. 22nd edition. Newyork: McGraw- Hill; 2001.

10. Norrby SR. Urinary tract infections In: Finch RG, Greenwood D, Norrby SR, and Whitley RJ. Antibiotic and Chemotherapy. 8th edition. Toronto: Churchill Livingstone; 2003.

11. Erayman İ, Erayman B and Arıbaş ET. İdrar örneklerinden izole edilen gram negatif bakterilerin antibiyotik duyarlılıkları. ANKEM Dergi; 2001.

12. Tenover FC, Arbeit RD, Goering RV, Mickelsen PA, Murray BE, Persing DH and Swaminathan B. Interpreting chromosomal DNA restriction patterns produced by pulsed-field gel electrophoresis, criteria for bacterial strain typing, J Clin Microbiol, 1995.

13. Olive DM and Bean P. Principles and Applications of Methods for DNA-Based Typing of Microbial Organisms, Journal Of Clinical Microbiology, 1999.

14. Nameghi SA. Genotyping Escherichia coli isolates by Pulsed-Field Gel Electrophoresis, MSc Thesis, Biolabs, Södertörn Högskola Stockholm, New England, 2007.

15. Schwartz DC, Saffran W, Welsh J, Haas R, Goldenberg M and Cantor CR. New techniques for purifying large DNAs and studying their priorities and packaging, Cold Spring Harbor Symposia on Quantitative Biology, 1982.

16. Kaufmann M, Woodford N and Alan PJ. Molecular bacteriology Protocoly and Clinical Applications. Humana Press; 1998.

17. Félix B, Dao TT, Lombard B, Brisabois AAA and Roussel S. The Use of Pulsed Field Gel Electrophoresis in Listeria monocytogenes Sub-Typing Harmonization at the European Union Level, Gel Electrophoresis -Principles and Basics (Edited by Magdeldin S.), 2012.

18. Basım E, Basım H. Pulsed-Field Gel Electrophoresis (PFGE) Technique and its use in Molecular Biology, Turk J Biol, 2000;25:405-418.

19. Carle GF, Frank M and Olson MV. Electrophoretic separations of large DNA molecules by periodic inversion of the electric field. Science, 1986;232(4746):65-68. 
20. Southern EM, Anand R, Brown WR and Fletcher DS. A model for the separation of large DNA molecules by crossed-field gel electrophoresis, Nucl. Acids Res. 1987.

21. Martinović A, Radulović Z, Wind A, Janzen T and Obradović D. Isolation and characterization of bacterial flora from farmhouse fermented milk products of Serbia and Montenegro. Acta Veterinaria, 2005; 55(4):307-318.

22. Shah A, Hasan F, Ahmed S and Hameed A. Characteristics, epidemiology and clinical importance of emerging strains of gram negative bacilli producing extended spectrum beta-lactamases, Research in Microbiology, 2005.

23. Berezin BE and Towner KJ. Acinetobacter spp as nosocomial pathogens: microbiological, clinical and epidemiological features, Clinic Microbiol Review, 1996.

24. Durmaz R. IV. Uygulamalı Moleküler Mikrobiyoloji Kursu Kitapcığı Malatya; 2007.

25. Singh A, Goering RV, Simjee S, Foley SL and Zervos MJ. Application of molecular techniques to the study of hospital infection, Clinic Microbiol Review, 2006.

26. Seifert H, Schulze A, Baginski R and Pulverer G. Plasmid DNA fingerprinting of Acinetobacter species other than Acinetobacter baumannii, J Clin Microbiol, 1994.

27. Bergogne-Berezin E and Joly-Guillou ML. Hospital infection with Acinetobacter spp.: anincireasing problem, J Hosp Infect, 1991.

28. Andrei A and Zervos MJ. The application of molecular techniques to the study of hospital infection, Arch pathol lab med, 2006; 130(5):662-668.

29. Dijkshoorn L., Michel MF, Degener J and Cell E. Envelope protein profiles of Acinetobacter Calcoaceticus strains isolated in hospitals, J Med Microbiol, 1987. 